\title{
First report of antibodies to Neospora spp. in horses from Portugal
}

\author{
Primeira ocorrência de anticorpos anti-Neospora spp. em cavalos de Portugal

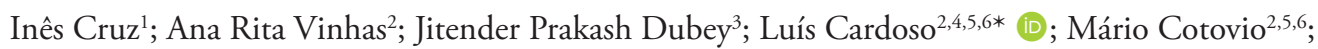 \\ Ana Patrícia Lopes ${ }^{2,4,6}$
}

\begin{abstract}
${ }^{1}$ Old Church Veterinary Hospital, Ballyshannon, County Donegal, Ireland
${ }^{2}$ Departamento de Ciências Veterinárias, Escola de Ciências Agrárias e Veterinárias, Universidade de Trás-os-Montes e Alto Douro UTAD, Vila Real, Portugal

${ }^{3}$ Animal Parasitic Diseases Laboratory, Beltsville Agricultural Research Center - BARC, Agricultural Research Service - ARS, United States Department of Agriculture - USDA, Beltsville, Maryland, USA

${ }^{4}$ Laboratório de Parasitologia, Escola de Ciências Agrárias e Veterinárias - ECAV, Universidade de Trás-os-Montes e Alto Douro UTAD, Vila Real, Portugal

${ }^{5}$ Hospital Veterinário, Universidade de Trás-os-Montes e Alto Douro - UTAD, Vila Real, Portugal

${ }^{6}$ Centro de Ciências Animal e Veterinária - CECAV, Universidade de Trás-os-Montes e Alto Douro - UTAD, Vila Real, Portugal
\end{abstract}

Received July 1, 2018

Accepted October 9, 2018

\begin{abstract}
Neospora spp. are intracellular protozoa with worldwide distribution and closely related to Toxoplasma gondii, which can infect a variety of mammals including horses. From September 2013 to June 2014, 185 horses from northern, central and southern parts of mainland Portugal were randomly sampled and tested for detection of immunoglobulin (Ig) G antibodies to Neospora spp. using an indirect multi-species enzyme-linked immunosorbent assay (ELISA) commercial test (ID Screen Neospora caninum Indirect Multi-species; ID.vet Innovative Diagnostics, Grabels, France). Two horses (1.1\%; CI: $0.1-3.8 \%)$, one male and one female, were found to be seropositive for Neospora spp. Both seropositive animals were horses housed indoors but with access to outdoors, used for leisure activities and were apparently healthy, with good body condition and with no alterations at physical examination. This was the first serologic survey of antibodies to Neospora spp. carried out in horses from Portugal.
\end{abstract}

Keywords: Enzyme-linked immunosorbent assay, horse, Neospora, seroprevalence, Portugal.

\section{Resumo}

Neospora spp. são protozoários intracelulares com distribuição mundial e estreitamente relacionados com Toxoplasma gondii, que podem infectar uma variedade de mamíferos, incluindo cavalos. De setembro de 2013 a junho de 2014, 185 cavalos de áreas do Norte, Centro e Sul de Portugal continental foram aleatoriamente amostrados e testados para a detecção de anticorpos imunoglobulinas (Ig) G anti-Neospora spp., utilizando-se um ensaio imunoenzimático (ELISA) indireto multi-espécies comercial (ID Screen Neospora caninum Indirect Multi-species; ID.vet Innovative Diagnostics, Grabels, France). Dois cavalos (1,1\%; IC: $0,1-3,8 \%$ ), um macho e uma fêmea, foram detectados como seropositivos para Neospora spp. Ambos os animais seropositivos eram cavalos mantidos em cocheiras mas com acesso aos piquetes, eram utilizados para atividades de lazer e estavam aparentemente saudáveis, com boa condição corporal e sem alteraçóes ao exame físico. Essa é o primeiro rastreio de anticorpos para Neospora spp. realizado em cavalos de Portugal.

Palavras-chave: Ensaio imunoenzimático, cavalo, Neospora, seroprevalência, Portugal.

Neosporosis is a parasitic disease of livestock and wild animals (DUBEY et al., 2017). It can cause a variety of clinical syndromes, including abortion and neurological signs. There are two species

*Corresponding author: Luís Cardoso. Departamento de Ciências Veterinárias, Escola de Ciências Agrárias e Veterinárias - ECAV, Universidade de Trás-os-Montes e Alto Douro - UTAD, Quinta de Prados, 5000-801, Vila Real, Portugal. e-mail: lcardoso@utad.pt of Neospora: $N$. caninum with a wide host range and $N$. hughesi with infection confined to horses (DUBEY et al., 2017). Canids (domestic and wild dogs, and wolves) are definitive hosts for $N$. caninum; definitive hosts for $N$. hughesi are unknown. Neospora hughesi has been reported to cause neurological disease and abortion in horses and histologically confirmed fatal $N$. hughesi infection in horses have been reported only from Canada and the 
USA (MARSH et al., 1996; WOBESER et al., 2009). However, Neospora DNA was found in tissues of aborted equine fetuses in France (PITEL et al., 2003).

There are several reports of Neospora seroprevalence in equids from many countries, but none from Portugal. Under this circumstance, the present study aimed at assessing the seroprevalence of Neospora spp. in a sample of the domestic horse population living in Portugal.

Horses $(n=185)$ from different areas of northern, central and southern mainland Portugal were randomly blood-sampled from September 2013 to June 2014. Available categorical data and distribution of animals are presented in Table 1. Data were obtained via personal interviews with the owners using a questionnaire. Information included geographical area, gender, age, aptitude, type of housing, contact with dogs and clinical status. The age of horses ranged from 1.0 to 28.0 years (median: 9.0 years, interquartile range: 5.0-14.0). Prior to every blood sample collection, by venepuncture of a jugular into tubes without anticoagulant, a physical examination was performed.

Blood samples were centrifuged at 1,500 g for 15 minutes and serum was stored at $-20{ }^{\circ} \mathrm{C}$ until testing. All serum samples were tested for detection of immunoglobulin (Ig) G antibodies to Neospora using an indirect multi-species enzyme-linked immunosorbent assay (ELISA) commercial test (ID Screen Neospora caninum Indirect Multi-species; ID.vet Innovative Diagnostics, Grabels, France) according to the manufacturer's instructions. This test has been described as having a sensitivity of $99.6 \%$ and a specificity of $97.3 \%$ for the serological diagnosis of bovine neosporosis (ÁLVAREZ-GARCÍA et al., 2013)

The Fisher's exact test was used to compare seropositivity values among categories of the same independent variables, with a probability $(p)$ value $<0.05$ as statistically significant. An exact binomial 95\% confidence interval (CI) was established for the whole seroprevalence. Analyses were done using the IBM SPSS Statistics 20 and the StatLib softwares.

This study was ethically approved as complying with the Portuguese legislation for the protection of animals (Law no. 92/1995 and Decree-Law no 113/2013). Owners provided their signed informed consent for inclusion of their animals in the study.

Two horses (1.1\%; CI: 0.1-3.8\%) were found to be seropositive for Neospora spp. The two samples, from a male and a female, had optical densities of 1.015 and 1.333, and 58.26 and 61.4 relative index per cents, respectively. The 4-year-old female was from southern Portugal; while the 24-year-old male horse lived in central Portugal. Both seropositive animals were horses housed indoors but with access to outdoors (mixed housing), used for leisure activities and were apparently healthy, with good body condition and no alterations at physical examination. Regarding contact with dogs, only the male horse had daily contact with those animals (Table 1). Statistical analyses revealed no significant differences of seropositivity to Neospora spp. for categories within geographical area, gender, age, aptitude, housing, contact with dogs and clinical status.

The present serosurvey represents the first epidemiological study of Neospora spp. carried out in horses from Portugal. Information from this country on Neospora spp. infection in animals is scarce. Studies of $N$. caninum have been conducted in dogs and dairy
Table 1. Data on horses tested for antibodies to Neospora spp., from Portugal.

\begin{tabular}{lcc}
\hline Variable/category & $\begin{array}{c}\text { Horses tested } \\
\text { (n) }\end{array}$ & $\begin{array}{c}\text { Relative distribution } \\
(\%)\end{array}$ \\
\hline Geographical area & & \\
Northern & 33 & 17.8 \\
Central & $59^{\mathrm{a}}$ & 31.9 \\
Southern & $93^{\mathrm{b}}$ & 50.3 \\
Gender & & \\
Male & $113^{\mathrm{a}}$ & 61.1 \\
Female & $72^{\mathrm{b}}$ & 38.9 \\
Age (years) & & \\
1-6 & $68^{\mathrm{b}}$ & 36.8 \\
7-12 & 60 & 32.4 \\
13-28 & $57^{\mathrm{a}}$ & 30.8 \\
Aptitude & & \\
Sport & 96 & 51.9 \\
Leisure & $67^{\mathrm{a}, \mathrm{b}}$ & 36.2 \\
Reproduction & 13 & 7.0 \\
Work & 9 & 4.9 \\
Housing & & \\
Indoors & 50 & 27.0 \\
Mixed & $81^{\mathrm{a}, \mathrm{b}}$ & 43.8 \\
Outdoors & 54 & 29.2 \\
Contact with dogs & & 68.1 \\
Yes & $126^{\mathrm{a}}$ & 31.9 \\
No & $59^{\mathrm{b}}$ & \\
Clinical status & & \\
Apparently healthy & $174^{\mathrm{a}, \mathrm{b}}$ & \\
Sick & 11 & \\
Total & & \\
\hline & & \\
\hline
\end{tabular}

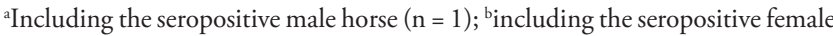
horse $(\mathrm{n}=1)$; ${ }^{\mathrm{c}}$ no detectable clinical manifestations on physical examination;

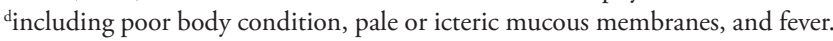

cows in Portugal with a seroprevalence of $7.9 \%$ in domestic dogs (MAIA et al., 2014) and 46.0\% in dairy cows with a history of abortion (CANADA et al., 2004).

In the present study, antibodies to Neospora spp. were detected in two $(1.1 \%)$ out of 185 horses. Results of the present study are not comparable to $0-63 \%$ seropositivity in horses from many countries (DUBEY et al., 1999; ANTONELLO et al., 2012) because of different serological tests employed. The low seropositivity is not related to $N$. caninum antigen used in the ELISA test because $N$. caninum cross reacts serologically with $N$. hughesi and most previous serological surveys were based on using $N$. caninum antigen. All available commercial tests use $N$. caninum as antigen. Different ELISAs have been used for the detection of Neospora antibodies (ÁLVAREZ-GARCÍA et al., 2013).

In the present study, it was not possible to establish an association between antibodies to Neospora spp. and categories of the variables aptitude and housing. Both animals were housed indoors with access to the outside in the paddock (mixed housing), as part of their leisure activities. Nevertheless, Villalobos et al. (2012) suggested that working horses in urban areas and horses living in 
rural regions had a higher risk of acquiring Neospora spp. due to a greater probability of exposure to dog's feces and to an environment contaminated with sporulated oocysts of these protozoa.

Results obtained from the present investigation suggest that, although most of the horses tested (68.1\%) contacted or regularly lived with dogs, the latter do not seem to represent a risk, since only one seropositive horse had contact with dogs. Kligler et al. (2007), in Israel, and Abreu et al. (2014), in Brazil, reported a positive correlation between breeding mares with reproductive problems and the presence of dogs seropositive to Neospora. According to these same authors, the risk may be higher if cattle are present, since their presence together with dogs allows the parasite's cycle to be maintained and is a constant threat to intermediated hosts, including horses.

It is concluded that the seroprevalence of Neospora spp. in horses from mainland Portugal is low. However, further studies are needed in order to better understand the impact of Neospora infections on the equine population, especially regarding the host-parasite relationship, epidemiology, pathogenesis and new diagnostic techniques.

\section{Acknowledgements}

The authors would like to thank Mr. Philippe Bevilacq and Mrs. Amanda Barthès, from ID.vet Innovative Diagnostics (Grabels, France), who kindly provided the Neospora commercial kit (ID Screen ${ }^{\circledR}$ Neospora caninum Indirect Multi-species). Acknowledgments are also extended to all the horse owners who contributed to this study. This study was funded by the project UID/CVT/00772/2013 and UID/CVT/00772/2016 supported by the Portuguese Science and Technology Foundation (FCT).

\section{References}

Abreu RA, Weiss RR, Thomaz-Soccol V, Locatelli-Dittrich R, Laskoski LM, Bertol MA, et al. Association of antibodies against Neospora caninum in mares with reproductive problems and presence of seropositive dogs as a risk factor. Vet Parasitol 2014; 202(3-4): 128-131. http://dx.doi. org/10.1016/j.vetpar.2014.03.022. PMid:24731383.

Álvarez-García G, García-Culebras A, Gutiérrez-Expósito D, NavarroLozano V, Pastor-Fernández I, Ortega-Mora LM. Serological diagnosis of bovine neosporosis: a comparative study of commercially available ELISA tests. Vet Parasitol 2013; 198(1-2): 85-95. http://dx.doi.org/10.1016/j. vetpar.2013.07.033. PMid:23953144.

Antonello AM, Pivoto FL, Camillo G, Braunig P, Sangioni LA, Pompermayer E, et al. The importance of vertical transmission of Neospora sp. in naturally infected horses. Vet Parasitol 2012; 187(3-4): 367-370. http:// dx.doi.org/10.1016/j.vetpar.2012.02.005. PMid:22436425.

Canada N, Carvalheira J, Meireles CS, Correia da Costa JM, Rocha A. Prevalence of Neospora caninum infection in dairy cows and its consequences for reproductive management. Theriogenology 2004; 62(7): 1229-1235. http://dx.doi.org/10.1016/j.theriogenology.2004.01.004. PMid:15325549.

Dubey JP, Hemphill A, Calero-Bernal R, Schares G. Neosporosis in animals. Boca Raton: CRC Press; 2017. http://dx.doi.org/10.1201/9781315152561.

Dubey JP, Kerber CE, Granstrom DE. Serologic prevalence of Sarcocystis neurona, Toxoplasma gondii, and Neospora caninum in horses in Brazil. J Am Vet Med Assoc 1999; 215(7): 970-972. PMid:10511862.

Kligler EB, Shkap V, Baneth G, Mildenberg Z, Steinman A. Seroprevalence of Neospora spp. among asymptomatic horses, aborted mares and horses demonstrating neurological signs in Israel. Vet Parasitol 2007; 148(2): 109113. http://dx.doi.org/10.1016/j.vetpar.2007.06.002. PMid:17614202.

Maia C, Cortes H, Brancal H, Lopes AP, Pimenta P, Campino L, et al. Prevalence and correlates of antibodies to Neospora caninum in dogs in Portugal. Parasite 2014; 21: 29. http://dx.doi.org/10.1051/parasite/2014031. PMid:24972327.

Marsh AE, Barr BC, Madigan J, Lakritz J, Nordhausen R, Conrad PA. Neosporosis as a cause of equine protozoal myeloencephalitis. J Am Vet Med Assoc 1996; 209(11): 1907-1913. PMid:8944807.

Pitel PH, Romand S, Pronost S, Foucher N, Gargala G, Maillard K, et al. Investigation of Neospora sp. antibodies in aborted mares from Normandy, France. Vet Parasitol 2003; 118(1-2): 1-6. http://dx.doi.org/10.1016/j. vetpar.2003.10.007. PMid:14651869.

Villalobos EMC, Furman KE, Lara MCCSH, Cunha EMS, Finger MA, Busch APB, et al. Detection of Neospora sp. antibodies in cart horses from urban areas of Curitiba, Southern Brazil. Rev Bras Parasitol Vet 2012; 21(1): 68-70. http://dx.doi.org/10.1590/S1984-29612012000100014. PMid:22534949.

Wobeser BK, Godson DL, Rejmanek D, Dowling P. Equine protozoal myeloencephalitis caused by Neospora hughesi in an adult horse in Saskatchewan. Can Vet J 2009; 50(8): 851-853. PMid:19881924. 